\title{
Геномное редактирование цианобактерий с целью получения промышленно значимых продуктов
}

Кувырченкова А.П.

Национальный исследовательский центр «Курчатовский институт», Москва, Россия e-mail: kuvyrchenkova@phystech.edu

Ключевые слова: цианобактерия, геномное редактирование, производство продукта

Мотивация и цель: Цианобактерии - это фотоавтотрофные бактерии, которые содержат хлорофилл «а» и осуществляют фотосинтез сходным образом с высшими растениями. Преимущество использования данных микроорганизмов в том, что они нуждаются только в солнечном свете, воде и воздухе. Выбор же продукта, который будет производит цианобактерия, зависит от нескольких факторов: прежде всего производство должно быть экономически выгодно, в том числе по сравнению с традиционными способами производства данного продукта, производимый продукт должен легко выделяться из среды с цианобактериями, не менее важна безопасность для человека самого продукта и производства в целом, относительная автономность производства продукта также является преимуществом при выборе.

Meтоды и алгоритмы: Генетичекий перенос молекулы ДНК в клетку цианобактерии может быть осуществлен в результате электропорации или естественных способов передачи ДНК: трансформации, коньюгации и трансдукции. Трансформируемый генетический материал возможно получить из других организмов, производящих интересуемый нас продукт.

Одноклеточная цианобактерия Synechococcus sp. PCC 7942 первая цианобактерия, для которой описана генетическая трансформация [1]. Затем трансформация была описана для штамма одноклеточной цианобактерии Synechocystis. sp. PCC 6803 [2], способного расти в темноте на глюкозе [3]. Этот штамм сыграл главную роль в изучении цианобактериального фотосинтеза.

Заключение: Цианобактерии представляют собой значительный, но на данный момент малоиспользуемый, ресурс для получения огромного количества различных промышленно значимых продуктов. Все чаще появляются разработки с использованием этих древнейших микроорганизмов. Простота в уходе и доступность методов геномного редактирования цианобактерий позволяет найти им применение в биотехнологии для производства специфических продуктов, включая биотопливо, лекарственные препараты, продукцию косметической промышленности, а также многие другие необходимые продукты.

Благодарности: источник финансирования Соглашение с Минобрнауки № 075-15-2019-1659 от 31.10.2019

Список литературь

1. Shestakov S.V., Khyen N.T. Mol. Gen. Genet. 1970. V. 107. P. 372.

2. Grigorieva G., Shestakov S. FEMS Microbiol. Lett. 1982. V. 13. P. 367.

3. Anderson S.L., McIntosh L. J. Bacteriol. 1991. V. 173. P. 2761. 